\title{
Evidence of Chlamydia trachomatis infection in sexually acquired reactive arthritis
}

\author{
A. C. KEAT, ${ }^{1}$ B. J. THOMAS, ${ }^{1}$ D. TAYLOR-ROBINSON, ${ }^{1}$ \\ G. D. PEGRUM, ${ }^{2}$ R. N. MAINI, ${ }^{3}$ AND J. T. $\operatorname{SCOTT}^{3}$
}

From the ${ }^{1}$ Division of Communicable Diseases, Clinical Research Centre, Watford Road, Harrow, Middlesex HAl 3UJ, the ${ }^{2}$ Department of Haematology, Charing Cross Hospital Medical School, St Dunstan's Road, London W6 8RF, and the ${ }^{3}$ Clinical Research Division, Mathilda and Terence Kennedy Institute of Rheumatology, Bute Gardens, London W6 7DW

SUMMARY Thirty male patients with sexually acquired reactive arthritis (SARA) have been studied at the time of their initial presentation and thereafter. Chlamydia trachomatis was isolated from the urethral exudate of $9(36.0 \%)$ of the 25 patients from whom urethral specimens were taken, and elevated titres of IgM antibody to $C$. trachomatis were detected in $11(36 \cdot 6 \%)$ of the 30 initial sera. Thirteen $(43.3 \%)$ of the patients had a positive urethral culture and/or elevated titre of IgM antibody, and it is therefore suggested that $43 \cdot 3 \%$ of these patients suffered an acute chlamydial infection at or near the time of the onset of their joint disease. The demonstration of 4-fold or greater rises and/ or falls in IgM antibody titre (8 patients) and IgG antibody titre (6 patients) in a group of 15 men studied throughout the course of their disease strongly supports this conclusion. A positive urethral culture and/or raised titre of IgM serum antibody was also detected in $25(50 \%)$ of 50 men with uncomplicated nongonococcal urethritis (NGU), suggesting that the prevalence of chlamydial infections in the 2 conditions is similar. Titres of IgG serum antibody to C. trachomatis were, however, significantly higher in patients with SARA than in those with NGU or other rheumatic diseases, and in healthy controls. The geometric mean titres (GMT) of IgG serum antibody in patients with SARA, NGU, rheumatoid arthritis, ankylosing spondylitis, systemic lupus erythematosus, and in healthy controls were $1: 47 \cdot 5,1: 8 \cdot 6,1: 2 \cdot 2,1 ; 2.2,1: 3 \cdot 5$, and $1: 1 \cdot 4$, respectively. These findings suggest that an exaggerated antibody response to acute infection by $C$. trachomatis may be an important factor in the development of SARA in some but not all patients.

Reactive arthritis, which may be defined as acute sterile synovitis associated with a localised infection elsewhere in the body, ${ }^{1}$ is a well-recognised complication of sexually transmitted nongonococcal urethritis (NGU). This condition has been documented and referred to as sexually acquired reactive arthritis (SARA), ${ }^{2}$ and although the incidence is difficult to assess it is probably the commonest cause of acute arthritis among young adults in Great Britain. In only $25 \%$ of cases of SARA is the triad of features of Reiter's syndrome present. A genetic predisposition to the development of this condition, marked by the presence of the histocompatibility

\section{Accepted for publication 12 October 1979}

Correspondence to Dr A. C. Keat, Department of Rheumatology, Westminster Hospital, Horseferry Road, London SW1. determinant HLA B27 in $66 \%$ of patients, is widely recognised, as in other forms of reactive arthritis, but the cause of NGU and the exact nature of the relationship between NGU and SARA are uncertain. It is, however, a plausible hypothesis that antigens derived from the agents causing the urethritis are responsible for initiating inflammatory musculoskeletal and other lesions in genetically predisposed individuals.

Strong evidence has now accumulated from both human and animal studies that infection by Chlamydia trachomatis causes a substantial proportionperhaps about $50 \%$ - of cases of NGU, ${ }^{4-6}$ and we have therefore sought evidence that infection by this micro-organism may be important in the development of SARA. We have previously reported the isolation of $C$. trachomatis from the urethra of 5 of 14 patients presenting with SARA. ${ }^{7}$ However, it is 
unlikely that isolation of the micro-organism alone can either reflect the true rate of infection, as a detectable antibody response to $C$. trachomatis occurs in some patients with NGU from whom an isolate cannot be obtained, ${ }^{89}$ or indicate whether or not this infection is of special significance in the initiation of SARA. Moreover, since it is likely that specific immune responses and aspects of antigen handling play a central role in the development of this condition, we consider that an assessment of the immune response to $C$. trachomatis in patients with SARA may provide a crucial first step to the understanding of its pathogenesis.

We have therefore attempted to assess both the prevalence of $C$. trachomatis infection and also quantitative aspects of the humoral immune response to this micro-organism in SARA compared with uncomplicated urethritis, using a modification of the microimmunofluorescence method of Wang and Grayston, ${ }^{10}$ which provides a sensitive, specific, and reproducible method for detecting and quantifying the different immunoglobulin classes of antibody to chlamydiae in man. ${ }^{11} 12$

\section{Patients, materials and methods}

Thirty male patients with sexually acquired reactive arthritis (SARA) were studied at the time of their presentation to venereology or rheumatology departments of the Charing Cross and West London Hospitals, London, as part of a prospective study. The diagnosis of SARA was based on the presence of sterile synovitis, with or without additional features, occurring in association with definite, sexually acquired NGU, according to a previous clinical study ${ }^{2}$; in 23 of the patients rheumatic symptoms had been present for less than 3 weeks. NGU was diagnosed if 10 or more polymorphonuclear leucocytes were seen per high-power field ( $\times 100$ objective) of a urethral smear, in association with negative tests for gonococci. ${ }^{13}$

A serum sample, defibrinated or citrated blood for HLA typing, and an endourethral swab for $C$. trachomatis culture were obtained from patients at presentation. Radiographs and other blood tests were performed as clinically indicated. A total of 34 synovial fluid samples (with corresponding sera) were obtained from 20 patients. All were cultured on routine bacteriological media with negative results and were shown to be free of crystals. Flexible and sometimes informal arrangements were made to follow up patients; blood samples were obtained at convenient intervals and the clinical features throughout the course of the rheumatic disease were documented. The severity and extent of disease features have been represented (see Fig. 3) on a simple arbitrary 0 to 5 scale. Fifteen patients with SARA who were first seen within 3 weeks of the onset of joint symptoms (mean 10 days) have been followed up throughout the course of their illness and for a variable period after cessation of all signs of disease activity. The mean duration of active rheumatic disease in these 15 patients was 13.6 weeks and the mean surveillance period was 36.5 weeks.

During the time of this study 555 men presenting to the venereology clinic with uncomplicated NGU were also studied. All were HLA typed for the presence or absence of HLA B27 by a modification of the microlymphocytotoxicity technique of Terasaki and McClelland, ${ }^{14}$ and satisfactory specimens of urethral exudate were obtained from 452 men for culture of $C$. trachomatis. Sera from 50 of these patients, of whom 14 yielded isolates of C. trachomatis, were randomly selected for chlamydial serology. All patients in both SARA and NGU groups received a standard course of antibiotic therapy (usually oxytetracycline), and when necessary this was supplemented by other antibiotics in order to achieve eradication of signs of urethritis.

Urethral material was cultured for C. trachomat $i$ ? in 5-iodo-2-deoxyuridine-treated $\mathrm{McCoy}$ cells, and antibodies to $C$. trachomatis of IgG and IgMB classes were sought by a quantitative microimmuno:fluorescence technique using immunotypes B, D, E, $\mathrm{F}, \mathrm{G}, \mathrm{H}, \mathrm{I}$, and $\mathrm{J}^{16}$ In accordance with data previously collected in our laboratory serum IgG titres of $1:<16$ were considered to be of doubtful significance. Changes in IgG titres between $1:<2$ and $1: 8$ are therefore not shown in Fig. 2a. IgM antibody titres of $1: \geqslant 2$ were regarded as signifying recent or current chlamydial infection.

Data on antibodies to $C$. trachomatis in other rheumatic disorders and in healthy individuals were obtained by testing groups of 30 sera withdrawn from storage $\left(-70^{\circ} \mathrm{C}\right)$ from patients with active rheumatoid arthritis (RA), systemic lupus erythematosus (SLE), and ankylosing spondylitis (AS) and from asymptomatic males of similar age distribution to the patients with SARA.

To assess whether serological responses were exclusive to $C$. trachomatis in the SARA patients antibodies to measles and rubella viruses were measured using standard complement-fixation tests and to influenza $\mathrm{A} /$ Victoria/3/75 virus by a standard haemagglutination-inhibition assay. This latter assay was also used to assess the relative concentrations of antibody to influenza virus in paired sera and synovial fluid samples. Immunoglobulin estimations were performed by a single radial-immunodiffusion technique with Behringwerke Tri-Partigen plates. In all tests in which levels or titres in serum and 
synovial fluid were compared both members of the pair were analysed simultaneously.

Statistical analyses of data were carried out as indicated in the text.

\section{Results}

PREVALENCE OF CHLAMYDIA TRACHOMATIS INFECTION

Urethral exudate from 25 of the 30 patients with SARA and from 452 unselected men with uncomplicated NGU was cultured for $C$. trachomatis. Isolates were obtained from $9(36.0 \%)$ and 165 $(36.6 \%)$ individuals respectively (Table 1$)$, the isolation rates being almost identical. Elevated titres of IgM antibody $(1: \geqslant 2)$ were detected in initial sera from $11(36.6 \%)$ of 30 patients with SARA and $21(42 \%)$ of 50 with NGU alone (Table 1). Evidence of current or recent $C$. trachomatis infection as indicated by positive urethral cultures or the presence of IgM serum antibody was found in 13 $(43 \%)$ of 30 patients with SARA and $25(50 \%)$ of

Table 1 Incidence of urethral isolates of $\mathrm{C}$. trachomatis and of elevated titres of IgM chlamydial antibody in $S A R A$ and $N G U$ (at presentation)

\begin{tabular}{|c|c|c|c|c|c|}
\hline & \multicolumn{2}{|l|}{ Culture } & \multicolumn{2}{|l|}{ Serology } & \multirow{2}{*}{$\begin{array}{l}\begin{array}{l}\text { Combined } \\
\text { data }\end{array} \\
\% \text { isolate } \\
+ \text { ve and } / o r \\
\text { IgM } 1: \geqslant 2\end{array}$} \\
\hline & $\begin{array}{l}\text { No. of } \\
\text { patients }\end{array}$ & $\%+v e$ & $\begin{array}{l}\text { No. of } \\
\text { patients }\end{array}$ & $\begin{array}{l}\% \operatorname{Ig} M \\
1: \geqslant 2\end{array}$ & \\
\hline $\begin{array}{l}\text { SARA } \\
\text { NGU }\end{array}$ & $\begin{array}{l}25 \\
452\end{array}$ & $\begin{array}{l}36 \cdot 0 \\
36 \cdot 6\end{array}$ & $\begin{array}{l}30 \\
50\end{array}$ & $\begin{array}{l}36 \cdot 6 \\
42 \cdot 0\end{array}$ & $\begin{array}{l}43 \\
50\end{array}$ \\
\hline
\end{tabular}

50 patients with uncomplicated NGU. Thus the prevalence of $C$. trachomatis infection is apparently similar in SARA and NGU.

IgG AND IgM CLASSES OF ANTIBODY

TO C. TRACHOMATIS

Titres at presentation

In spite of the prevalence of $C$. trachomatis infection being similar in SARA and NGU the magnitude of the IgG antibody titres in the 2 groups differed significantly $(P=\mathbf{0} \cdot 01$; Wilcoxon's sum of ranks test; Fig. 1a). Twenty-two of $30(73 \%)$ SARA patients and 26 of $50(52 \%)$ NGU patients had elevated titres of $\mathrm{IgG}$ antibody at presentation, the geometric mean titre (GMT) in each entire group being $1: 47 \cdot 5$ and $1: 8.6$ respectively. Furthermore, whereas all 9 of the isolate-positive patients with SARA had very high titres of IgG antibody $(1: \geqslant 128)$, only 1 of the $14 \mathrm{NGU}$ patients from whom chlamydiae were isolated had such a titre. The GMT of antibody in each of these isolate-positive groups was $1: 188$ and $1: 15 \cdot 2$ respectively.

Twelve patients with SARA and 11 of those with NGU gave a history of 1 or more previous episodes of NGU. It is therefore unlikely that the different antibody titres in the 2 groups of patients can be attributed to previous sensitisation to chlamydial antigens.

Although very high IgM antibody titres were detected in sera from 2 patients with SARA, the distribution of titres in the 2 groups of patients did not differ significantly (Wilcoxon's sum of ranks test; Fig. 1b).
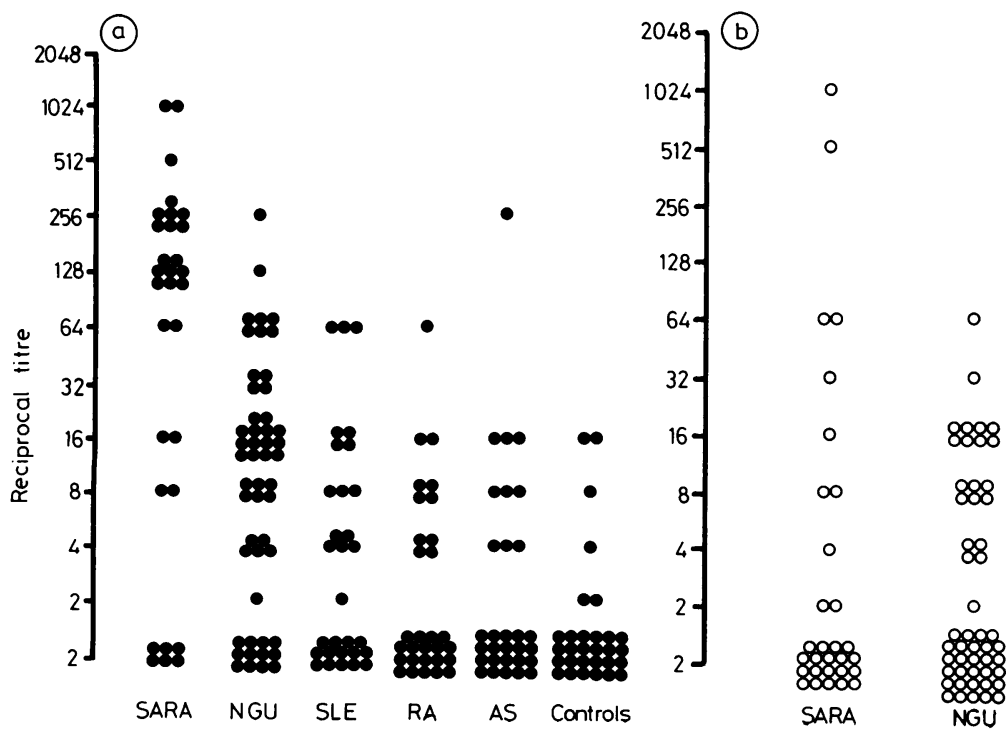

Fig. 1 Titres of antibody to $\mathrm{C}$. trachomatis in groups of 30 patients with $S A R A$, systemic lupus erythematosus (SLE), rheumatoid arthritis $(R A)$, ankylosing spondylitis $(A S)$, in 30 healthy male controls and in 50 patients with uncomplicated $N G U$. Fig. 1a: IgG antibody; Fig. 1b: IgM antibody (SARA and $N G U$ only). 


\section{Serial studies}

Eight of 15 patients with SARA studied serially had elevated titres of IgG antibody at presentation (Fig. 2a). Three of these had an 8-fold or greater rise in titre during the period of active joint disease and subsequently 6 patients, including these 3 , had a 4fold or greater fall in titre. The 2 remaining patients with elevated initial titres had no significant change during the period of surveillance. In contrast, no IgG antibody could be detected at any time during the course of disease in the sera of the remaining 7 patients (not shown). Six of the 8 chlamydial antibody-positive patients were also culture-positive while none of those without antibody were culturepositive.

Seven of the 15 SARA patients who were studied serially had IgM antibody in the intitial serum (Fig. $2 b$ ), and 1 of these subsequently had a 4-fold rise in titre; 1 patient without detectable IgM antibody in the initial serum developed a peak titre if $1: 16$, and subsequently a significant reduction in titre was demonstrated in all 8 , in 5 cases to $1: \leqslant 2$. These data strongly suggest an acute immune response to chlamydial antigens. Seven patients (not shown) who also lacked IgG antibody did not develop detectable IgM antibody at any time during the course of their disease.

\section{CORRELATION BETWEEN ANTIBODY TITRES} AND CLINICAL DISEASE FEATURES

The peak of the IgM antibody response occurred early in the course of disease, the highest titres being noted at presentation in almost all patients, but elevated titres of this antibody were short-lived (mean 24 weeks). The duration of this response bore no relationship to the presence of active joint disease. In contrast titres of IgG antibody, though often raised at presentation, reached a peak at 1 to 10 weeks (mean 6 weeks) from the onset of arthritis. In spite of a gradual downward trend thereafter in most patients, in none did the titre of IgG serum antibody fall below 1:16 during the period of observation and in 4 patients elevated titres persisted for more than 1 year after cessation of all symptoms. The changes in titre of IgG and IgM antibody during the course of SARA are illustrated by results from a single patient (Fig. 3).

The muscoluskeletal features of the 22 chlamydial antibody-positive patients did not differ in any way from those of the 8 others.

\section{RELATIONSHIP BETWEEN CHLAMYDIAL}

ANTIBODIES AND HLA PHENOTYPES

Twenty-nine of the patients with SARA were HLA typed, and, of these, $14(46.6 \%)$ possessed the antigen HLA B27. In contrast only 32 of 555 $(5.7 \%)$ men with uncomplicated NGU, and 20 of $280(7 \cdot 1 \%)$ healthy controls possessed this antigen. Initial titres of IgG and IgM antibody in the sera of SARA patients with and without the HLA B27 antigen are shown in Fig. 4. It is apparens that antibody titres of both classes are similarly distributed in the B27-positive and -negative groups.

\section{SYNOVIAL FLUID STUDIES}

Thirty-four corresponding pairs of serum and synovial fluid obtained from 20 patients were examined for the presence of IgG antibody to $C$. trachomatis.

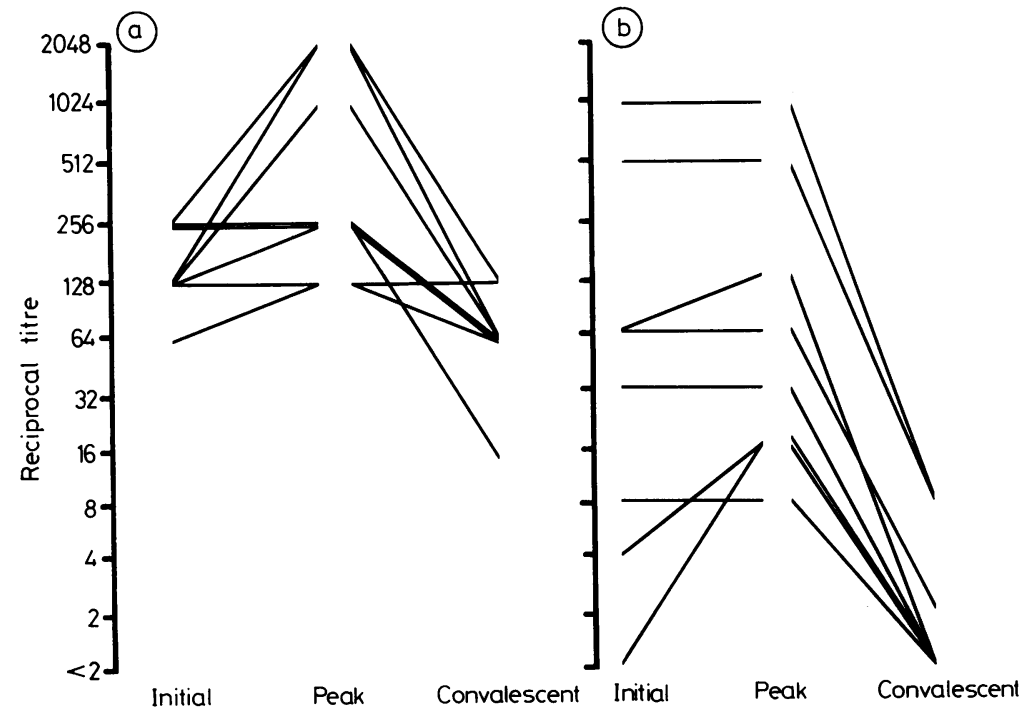

Fig. 2 Titres of IgG (Fig. 2a) and $\operatorname{Ig} M$ (Fig. 2b) antibody to $\mathrm{C}$. trachomatis at presentation (initial) and after resolution of the $\sigma$ disease (convalescent), showing the maximum titre (peak) reached for each patient during this period. 


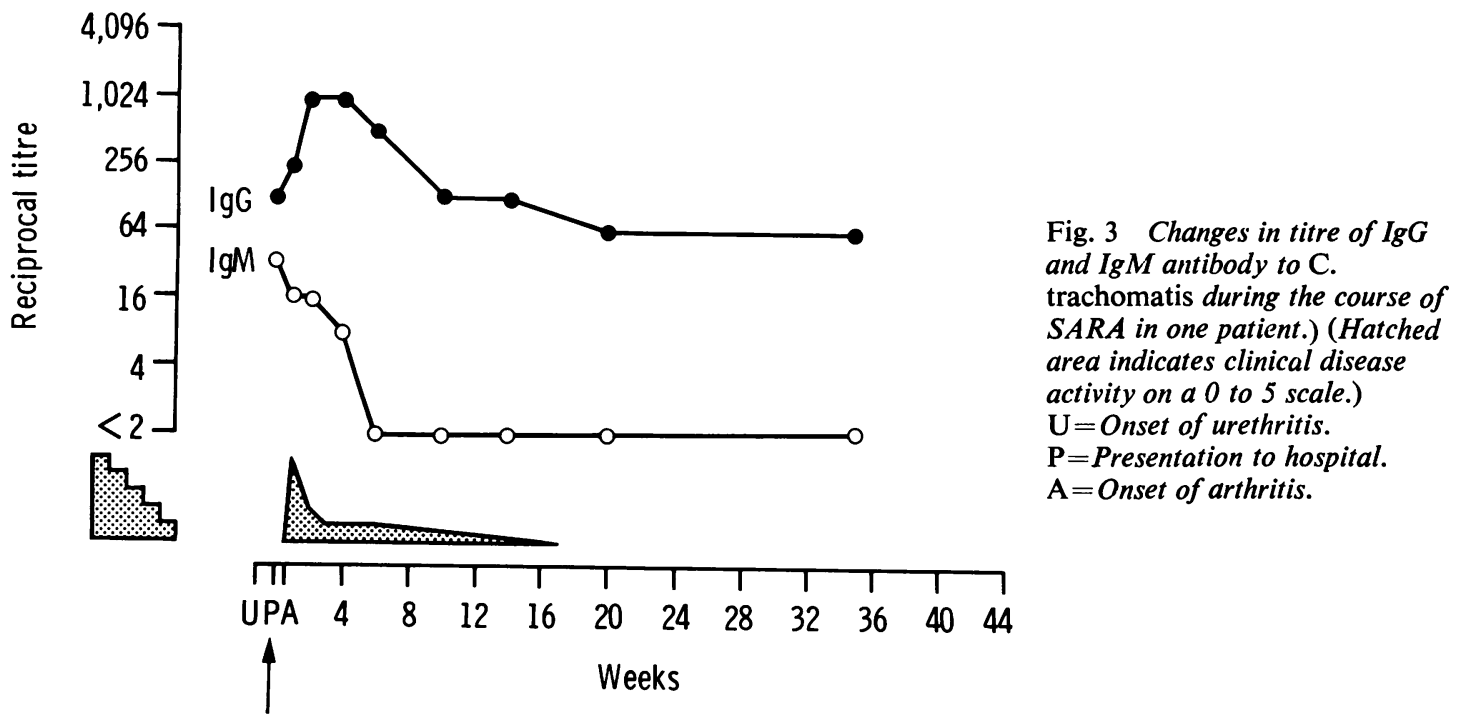

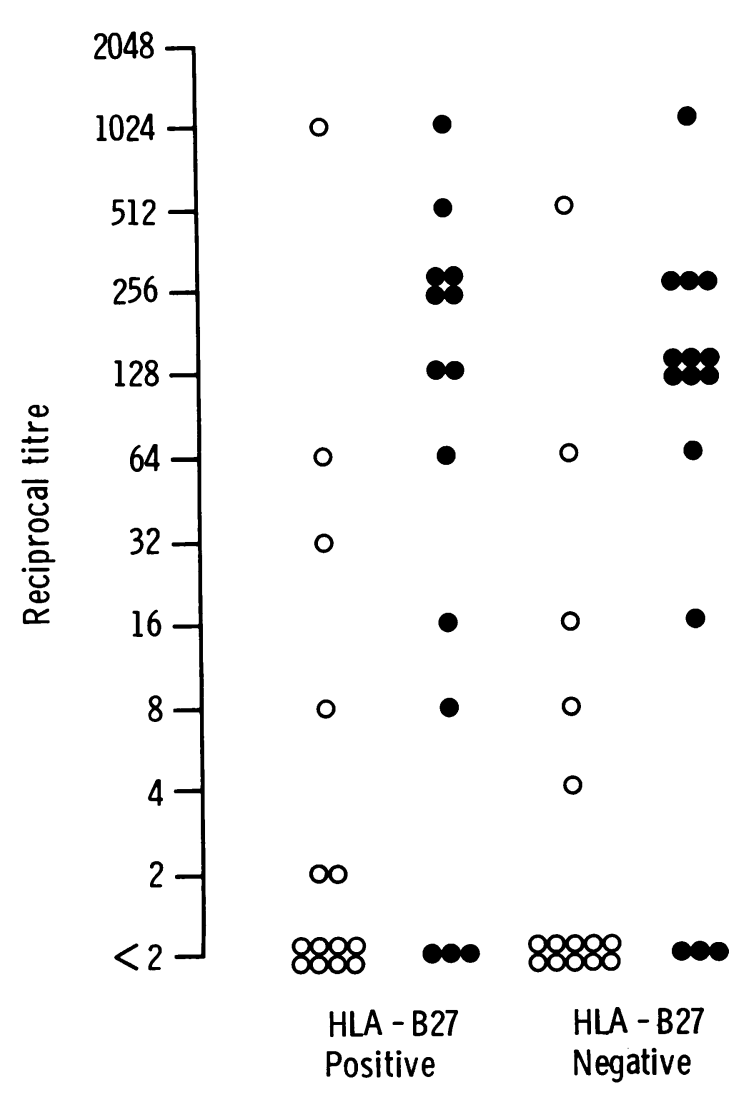

Fig. 4 Titres of IgG (closed circles) and IgM antibody (open circles) to $\mathrm{C}$. trachomatis in HLA B27-positive and negative patients with SARA.
Both members of each pair were tested in the same assay. Twenty-six of the sera had antibody titres of $1: 16$ or greater, as did 25 of the corresponding fluids, and in 31 of the pairs there was agreement between serum and synovial fluid antibody titres to within one 2-fold dilution. The GMT of antibody in the 34 sera was 1:59 and in the corresponding synovial fluids was 1:64. All patients had detectable antibody to influenza virus; the GMT of antibody in the 34 sera and in the corresponding synovial fluids was 1:9.4 and 1:8.6 respectively. The concentration of total IgG protein was also measured and the mean synovial fluid level $(6.46 \mathrm{~g} / \mathrm{l})$ was found to be approximately half that of the mean serum level $(13 \cdot 14 \mathrm{~g} / \mathrm{l})$.

\section{CONTROL STUDIES}

IgG antibody to $C$. trachomatis at a titre of $1: 16$ or greater was present in sera from 3 of $30(10 \%)$ patients with rheumatoid arthritis, 4 of $30(13 \%)$ with ankylosing spondylitis, 7 of $30(23 \%)$ with systemic lupus erythematosus, and 2 of $30(7 \%)$ sera from healthy male controls (Fig. 1a). The GMT of serum antibody in these groups was only $1: 2 \cdot 2$, $1: 2 \cdot 2,1: 3 \cdot 5$, and $1: 1 \cdot 4$ respectively, in marked contrast to that of $1: 47 \cdot 5$ in the SARA group (Table 2). It is apparent from Fig. 1a that the distributions of antibody titres in these control groups are essentially similar but that they differ markedly from that in the SARA group $(P<0.001$; Wilcoxon's sum of ranks test), antibody titres in NGU occupying an intermediate position.

Titres of antibody to measles, rubella, and influenza viruses were measured in single sera drawn 
Table 2 Frequency of elevated titres and geometric mean titres of IgG antibody to C. trachomatis in SARA, $N G U$ and control groups

\begin{tabular}{lllll}
\hline Population & $\begin{array}{l}\text { No. } \\
\text { examined }\end{array}$ & Titre & $1: \geqslant 16$ & \multirow{2}{*}{ GMT } \\
\cline { 4 - 5 } & & No. & $\%$ & \\
\hline Rheumatoid arthritis & 30 & 3 & 10 & $1: 2 \cdot 2$ \\
Ankylosing spondylitis & 30 & 4 & 13 & $1: 2 \cdot 2$ \\
Systemic lupus erythematosus & 30 & 7 & 23 & $1: 3 \cdot 5$ \\
Healthy males & 30 & 2 & 7 & $1: 1 \cdot 4$ \\
NGU & 50 & 26 & 52 & $1: 8 \cdot 6$ \\
SARA & 30 & 22 & 73 & $1: 47 \cdot 5$ \\
\hline
\end{tabular}

during the period of active synovitis: all were found to be within ranges normally found in adults currently uninfected by these viruses.

\section{Discussion}

The importance of this study lies in its clear demonstration of an exaggerated humoral immune response to chlamydial antigens which appears to characterise a high proportion of, though not all, patients with SARA. Since the concept of reactive arthritis implies that tissue damage in affected areas is brought about by the action of antibodies, immune complexes, sensitised cells and/or other inflammatory mediators arising from the focus of infection, which in the case of SARA lies within the genital tract, this finding suggests that the organism $C$.trachomatis or antigens derived from it may play a central role in the initiation of SARA.

The isolation of $C$. trachomatis from the urethra of $36 \%$ of men with SARA is consistent with the earlier findings of Vaughan-Jackson et al., ${ }^{17}$ who isolated the organism from 3 of 10 patients with Reiter's syndrome, but differs substantially from the $69 \%$ isolation rate found by Kousa et al..$^{18}$ in patients with Reiter's syndrome and active urethritis. Our isolation rate of $36.5 \%$ in men with uncomplicated NGU is consistent with other published data. ${ }^{4-6}$

It is clear from other studies in which the microimmunofluorescence test or a modification of it has been used that raised titres of IgG antibody to C. trachomatis are found in $70-100 \%$ of isolatepositive men with NGU and that similar titres also occur in $21-44 \%$ of those in whom cultures are negative. ${ }^{12} 1920$ Our data on both the SARA and NGU groups of patients are therefore comparable in this aspect, but in view of the duration of persistence of raised titres of IgG antibody after resolution of other signs of infection the significance of raised IgG titres as an indicator of infection is uncertain. In contrast, the short duration of the IgM antibody response suggests that detection of elevated titres of this class of antibody provides reasonable evidence of a recent or current chlamydial infection. We have therefore, regarded only raised titres of $\operatorname{IgM}$ antibody and/or isolation of $C$. trachomatis from the urethra as indicators of chlamydial infection around the time of onset of arthritis. Thus, while a higher proportion of patients with SARA had raised titres of IgG antibody (73\%) than those with NGU (52\%), our evidence indicates that approximately $40-50 \%$ of patients in both the SARA and NGU groups suffered an acute $C$. trachomatis infection at or near the time of onset of their disease. The demonstration of 4-fold or greater rises and falls in IgG titres (6 patients) and similar falls in IgM titres (8 patients) in approximately half of 15 patients studied serially strongly supports this conclusion. It is of interest that $7(27 \%)$ of the patients with SARA had negative urethral cultures and neither class of antibody detectable in their serum, indicating that in these individuals, at least, C. trachomatis infection is unlikely to be relevant to the pathogenesis of their disease.

In spite of the apparent similarity in rate of chlamydial infection in SARA and NGU our finding of high titres of IgG antibody to $C$. trachomatis in initial sera from the majority of patients with SARA (GMT 1:47.5), as compared with those with NGU alone (GMT 1:8.6), confirms the data of Kousa and colleagues. ${ }^{18}$ The fact that the humorabe immune response to this micro-organism was profoundly different in the 2 groups of patients is further emphasised by the demonstration of serial changes in antibody titre in the SARA patients, a finding which has been seen less convincingly in the case of NGU. Thus, although some authors have reported seroconversion from the absence of detectable antibody to titres of $1:>8$ in some patients with NGU, ${ }^{13} 20$ other workers have been unable to demonstrate this phenomenon at all. ${ }^{81}$ Serial studies were not performed on our patients with uncomplicated NGU owing to difficulties in maintaining long-term follow-up. No firm data are available on the duration of antibody persistence after NGU, but it is clear from our study that in SARA, whereas IgM antibody is usually short-lived, IgG may remain in the circulation for periods in excess of 1 year after all cessation of apparent disease.

It may be suggested that these changes in antibody titre are not peculiar to SARA. We therefore examined sera from patients with other rheumatic diseases, including ankylosing spondylitis, which resembles SARA in predominantly affecting HLA B27-positive individuals. In these patients, however, the antibody response to chlamydiae was comparable to that of healthy controls. We are aware, however, that groups of patients with chronic disease, whose sera were not examined at a similar early stage, may not constitute optimal controls. The possibility 
that these high titres of antibody found in SARA have been produced as part of a polyclonal immune response remains, though the absence of abnormally high titres of antibody to common viruses tends to militate against this.

It has previously been reported that the presence of the HLA B27 antigen does not influence susceptibility to $C$. trachomatis infection per $\mathrm{se}^{22}$ and it is now clear from the present study that no direct relationship exists between the presence of B27 and titres of IgG or IgM chlamydial antibody. However, since high titres of antibody are associated with disease, and therefore epidemiologically with B27, it may be that they are influenced by HLAlinked immune response genes. Since such genes may lie in the HLA D region, an analysis of HLA DW and DRW antigens may provide information to support or refute this possibility.

The presence of antibody in synovial fluid raises the possibility of local production, which may in turn indicate the presence of chlamydial antigens within the joint. In the absence of information on local antibody production in human arthritis in which micro-organisms are known to be present in the joint these data are impossible to interpret with certainty. However, the fact that antibody to influenza virus was distributed almost equally between serum and synovial fluid suggests that both types of antibody are derived from the circulation rather than from local intra-articular sources.

Thus it appears that $C$. trachomatis infection could be an initiating factor in approximately $50 \%$ of patients with SARA. The exaggerated antibody response to this organism in these patients may have very important pathogenetic implications, and this phenomenon certainly requires further study. Other trigger factors, however, remain to be identified.

We are grateful to Dr G. L. Ridgway, Miss Jean Owen, and Miss Veronique Lam Po Tang, Department of Medical Microbiology, University College Hospital, London, for carrying out the cultures for Chlamydia trachomatis, and to Dr J. L. Fluker, Department of Genitourinary Medicine, West London Hospital, London, for permission to study his patients. This work was supported by grants from the Arthritis and Rheumatism Council to G.D.P. and B.J.T.

\section{References}

1 Aho K, Ahvonen P, Lassus A, Sievers K, Tiilikainen A. HL-A 27 in reactive arthritis. A study of Yersinia arthritis and Reiter's disease. Arthritis Rheum 1974; 17: 521-6.

2 Keat A C, Maini R N, Pegrum G D, Scott J T. The clinical features and HLA associations of reactive arthritis associated with non-gonococcal urethritis. $Q J$ Med 1979; 48: 323-42.

3 Keat A C, Scott J T, Ridgway G L, Maini R N, Pegrum G F. Sexually acquired reactive arthritis. Ann Rheum Dis 1979; 38: Supplement, 52-4.
4 Dunlop E M C, Hare M J, Darougar S, Jones B R. Chlamydial infection of the urethra in men presenting because of 'non-specific' urethritis. In: Nichols R L, ed. Trachoma and Related Disorders. Amsterdam and New York: Excerpta Medica, 1971; 494-500.

5 Bowie W R, Wang S -P, Alexander E R, Holmes K K. Etiology of nongonococcal urethritis. In: Hobson D, Holmes K K, eds. Nongonococcal Urethritis and Related Infections. Washington D.C. American Society for Microbiology, 1977: 19-29.

6 Richmond S J, Oriel J D. Recognition and management of genital chlamydial infection. Br Med J 1978; 2: 480-3.

7 Keat A C, Maini R N, Nkwazi G C, Pegrum G D, Ridgway G L, Scott J T. Role of Chlamydia trachomatis and HLA-B27 in sexually acquired reactive arthritis. Br Med J 1978; 1 : 605-7.

8 Philip R N, Casper E A, Gordon F B, Quan A L. Fluorescent antibody responses to chlamydial infection in patients with lymphogranuloma venereum and urethritis. J Immunol 1974; 112: 2126-34.

9 Darougar S. Immunology of Chlamydia. In: Catterall R D, Nicol C S, eds. Sexually Transmitted Diseases. London: Academic Press, 1976: 111-120.

10 Wang S -P, Grayston J T. Immunologic relationship between genital TRIC, lymphogranuloma venereum, and related organisms in a new microtiter indirect immunofluorescence test. Am J Ophthalmol 1970; 70: 367-74.

11 Wang S -P, Grayston J T. Human serology in Chlamydia trachomatis infection with microimmunofluorescence. J Infect Dis 1974; 130: 388-97.

12 Reeve P, Gerloff R K, Casper E A, Philip R N, Oriel J D, Powis P A. Serological studies on the role of Chlamydia in the aetiology of nonspecific urethritis. Br J Vener Dis 1974; 50: 136-9.

13 Oriel J D, Reeve P, Powis P, Miller A, Nicol S C. Chlamydial infection. Isolation of Chlamydia from patients with non-specific genital infection. $\mathrm{Br} J$ Vener Dis 1972; 48: 429-36.

14 Terasaki P I, McClelland J D. Microdroplet assay of human serum cytotoxins. Nature 1964; 204: 998-1000.

15 Reeve P, Owen J, Oriel J D. Laboratory procedures for the isolation of Chlamydia trachomatis from the human genital tract. J Clin Pathol 1975; 28 : 910-4.

16 Thomas B J, Reeve P, Oriel J D. Simplified serological test for antibodies to Chlamydia trachomatis. J Clin Microbiol 1976; 4: 6-10.

17 Vaughan-Jackson J D, Dunlop E M C, Darougar S, Dwyer R St C, Jones B R. Chlamydial infection. Results of tests for Chlamydia in patients suffering from acute Reiter's disease, compared with results of tests of the genital tract and rectum in patients with ocular infection due to TRIC agent. Br J Vener Dis 1972; 48: 445-51.

18 Kousa M, Saikku P, Richmond S, Lassus A. Frequent association of chlamydial infection with Reiter's syndrome. Sex Transm Dis 1978; 5: 57-61.

19 Holmes K K, Handsfield H H, Wang S -P. et al. Etiology of nongonococcal urethritis. $N$ Engl J Med 1975; 292: 1199-204.

20 Bowie W R, Wang S -P, Alexander E R, et al. Etiology of non-gonococcal urethritis. Evidence for Chlamydia trachomatis and Ureaplasma urealyticum. J Clin Invest 1977; 59: 735-42.

21 Richmond S J, Caul E O. Fluorescent antibody studies in chlamydial infections. J Clin Microbiol 1975; 1: 345-52.

22 Keat A C, Maini R N, Nkwazi G C, Pegrum G D, Ridgway G L, Scott J T. HLA antigens. Chlamydia trachomatis infection and reactive arthritis. Tissue Antigens $1978 ; 12$ : $63-4$. 